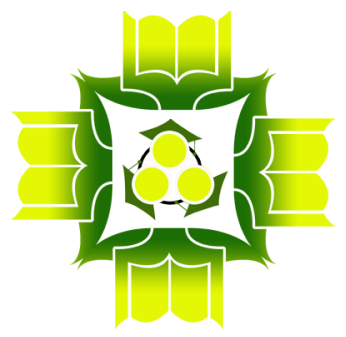

\title{
THE USE OF RISK BOARD GAME RULERS OF ARCHIPELAGO AS LEARNING MEDIA ON CREATIVE THINKING ABILITY OF ELEMENTARY SCHOOL STUDENTS
}

\author{
Yani Fitriyani \\ STKIP Muhammadiyah Kuningan \\ yanifitriyani@upmk.ac.id \\ Marlina Eliyanti \\ Universitas Kuningan \\ marlina@uniku.ac.id \\ Eli Hermawati \\ Universitas Kuningan \\ eli.hermawati@uniku.ac.id \\ Teguh Ramdan Fauzi \\ Universitas Kuningan \\ teguhzhie@gmail.com
}

\begin{abstract}
The low ability of students' creative thinking in social studies learning is shown by students who are less able to answer descriptive questions and also have not been able to provide ideas when answering a question. This study aims to describe the differences and improvement of students' creative thinking skills using the board game Risk Rulers of the Archipelago learning media using image media. This research includes quantitative research with a Quasi-Experimental approach, the research design is a Non-Equivalent Control Group Design. The subjects of this study were fifth-grade students of SD Negeri Pasayangan, Lebakwangi District, Kuningan Regency. Data collection was carried out using test instruments in the form of pretest and posttest description questions to measure students' creative thinking skills before and after the action. The data analysis of this research used instrument tests and statistical tests. The results showed that: (1) there were differences in students' creative thinking skills in the experimental class using the board game Risk Rulers of the Archipelago learning media and the control class
\end{abstract}


using image learning media. (2) there is an increase (gain) of student's creative thinking skills in the experimental class using the board game Risk Rulers of the Archipelago learning media and the control class using image learning media. The conclusion of this research is the use of board game learning media Risk Rulers of the Archipelago is very influential on students' creative thinking skills compared to those using image learning media.

Keywords: Social Studies; Creative Thinking Ability; Media Board Game Risk; Elementary School.

\begin{abstract}
Abstrak
Rendahnya kemampuan berpikir kreatif siswa pada muatan pembelajaran IPS ditunjukan dari siswa yang kurang mampu menjawab soal deskriptif dan juga belum mampu memberikan gagasan pada saat menjawab sebuah pertanyaan. Penelitian ini bertujuan untuk mendeskripsikan perbedaan dan peningkatan kemampuan berpikir kreatif siswa menggunakan media pembelajaran board game Risk Penguasa Nusantara menggunakan media gambar. Penelitian ini termasuk penelitian kuantitatif dengan pendekatan Quasi Eksperiment, desain penelitian Non-Equivalent Control Group Design. Subjek penelitian ini adalah siswa kelas V SD Negeri Pasayangan Kecamatan Lebakwangi Kabupaten Kuningan. Pengumpulan data dilakukan menggunakan intrumen tes berupa soal uraian pretest dan posttest untuk mengukur kemampuan berpikir kreatif siswa sebelum dan sesudah tindakan. Analisis data penelitian ini menggunakan uji instrumen dan uji statistik. Hasil penelitian menunjukan bahwa: (1) terdapat perbedaan kemampuan berpikir kreatif siswa pada kelas eksperimen yang menggunakan media pembelajaran board game Risk Penguasa Nusantara dengan kelas kontrol yang menggunakan media pembelajaran gambar. (2) terdapat peningkatan (gain) kemampuan berpikir kreatif siswa pada kelas eksperimen yang menggunakan media pembelajaran board game Risk Penguasa Nusantara dengan kelas kontrol yang menggunakan media pembelajaran gambar. Kesimpulan dari penelitian ini adalah penggunaan media pembelajaran board game Risk Penguasa Nusantara sangat berpengaruh terhadap kemampuan berpikir kreatif siswa dibandingkan dengan yang menggunakan media pembelajaran gambar.
\end{abstract}

Kata Kunci : IPS; Kemampuan Berpikir Kreatif; Media Board Game Risk; Sekolah Dasar.

\title{
INTRODUCTION
}

Creative thinking in elementary school students is a process where students think of various solutions to produce various possible answers to a problem they face (Suwandari et al., 2019). Creative thinking is a habit of the mind that is trained and pays attention to intuition, activates the imagination, reveals new 
possibilities, opens up amazing perspectives and develops unexpected ideas (Lucas, 2019). Thus the demands of problem solving both in the realm of learning or real life, students are not fixated on one problem solving or only one answer, students are free to convey their answers according to their thoughts but still in accordance with the context of the problems at hand (Vidergor, 2017). The ability to think creatively is very important for every student. This is because the ability to think creatively in every learning content is very necessary, both in the process of achieving learning objectives or in an effort to achieve useful learning outcomes (Simbolon et al., 2021). Susanto (2017) said that in schools almost every subject can be used for the purposes of developing student creativity. It's just that the teacher must be able to package and polish each material or lesson in order to produce a creative learning model (Supriatna, 2019).

One of the subjects that can be used as a means to develop creativity is social studies lessons. The content of social studies subjects is very possible to train students to be able to think logically, critically, in detail, systematically, creatively, and innovatively (Fitriyani, 2021). The output after students take part in the learning process is not only a matter of understanding theory, but it is also expected that students will be able to develop their thinking power and be able to utilize and apply the learning experiences they have obtained in solving problems of everyday life (Zuraida, 2017). In accordance with the 2013 curriculum which refers to Law No. 20 of the Republic of Indonesia, it is stated that one of the goals of the national education system is to develop the potential of students to become creative human beings (Depdiknas, 2003). In addition, every graduate must be creative (Kemendikbud, 2016). This shows that creative thinking is one aspect that is expected to be achieved in the educational process. Social studies content is a lesson that must be taught to students at the level of formal education. Social studies is a science that is very important, especially the need for social skills is needed if students are faced directly with real life, such as how they interact with their environment and how they solve the social problems they face.

According to Susanto (2017) that indicators or characteristics for people who have the ability to think creatively, related to social studies education can be seen or measured from indications such as fluency, flexibility, and original thinking ability. originality), the ability to detail (elaboratory). Social studies 
requires students to be able to interact with their environment, to be able to solve social problems. In accordance with the indicators of creative thinking in which there is the ability to spark many ideas, answers, problem solving, or questions which are very supportive of students to be able to follow learning in class well, and be able to solve problems in their social environment, provide many ways or suggestions for do various things, and always think of more than one answer so as to make students able to have competitiveness in society. Therefore, students' creative thinking skills in social studies subject matter are very important for every student to master.

For this reason, teachers must be able to support and assist in the mastery process by stimulating and strengthening each characteristic of students' creative thinking abilities in the learning process carried out. However, in the process that occurs in reality, social studies learning is only considered as a learning content that contains theories and long sentences that must be memorized, plus the material presented is not directly related to students' lives, conventional learning is delivered without involving students to participate. into learning, so that students do not have many opportunities to express their opinions and give their ideas, as a result students only listen and pay attention to the teacher's explanations and learning goes on with minimal interaction in it (Zevin, 2015). Kuntari (2019) explains some of the reasons for the emergence of common problems in the content of social studies subjects, such as conventional learning that is less able to attract the attention and interest of students to study social studies. The material presented is not directly related to student life, so students do not know the relationship between social studies learning and daily life so that it does not give a positive and pleasant impression to students in social studies learning (Setiawati et al., 2019). The absence of learning media that can provide real experiences and pleasant impressions for students on the learning they do can also be one of the obstacles to the development of students' creative thinking skills in the social studies learning process (Syawaluddin et al., 2020). This is evidenced by the results of initial observations of the acquisition of preresearch test scores on the content of social studies learning for the 2021 academic year as follows. 
The Use of Risk Board Game Rulers of Archipelago as Learning Media on Creative Thinking Ability ......

Table 1. Pre-research Results of Students' Creative Thinking Ability

\begin{tabular}{clcccc}
\hline No. & $\begin{array}{c}\text { Creative Thinking } \\
\text { Indicator }\end{array}$ & Appear & Percentage & $\begin{array}{c}\text { Has Not } \\
\text { Appeared }\end{array}$ & Percentage \\
\hline 1. & Fluency & 20 & $64 \%$ & 11 & $35 \%$ \\
2. & Flexibility & 16 & $51 \%$ & 15 & $48 \%$ \\
3. & Originality & 11 & $35 \%$ & 20 & $64 \%$ \\
4. & Elaboratory & 13 & $41 \%$ & 18 & $58 \%$ \\
\hline \multicolumn{5}{c}{ Source : SDN Pasayangan }
\end{tabular}

The data presented in table 1 above is data that shows the level of students' creative thinking abilities taken from the results of pre-research tests conducted on initial observations. Based on the data above, we can review the category of the percentage level of creative thinking ability of each student. Arikunto (2017) mentions the percentage level of $30 \%-55 \%$ as the low category, $56 \%-55 \%$ as the medium category, and $76 \%-100 \%$ as the high category, but based on the pretest at the beginning of the observation, the percentage obtained in the results the test only ranges at a percentage level of $35 \%$ to the maximum category at a percentage of $64 \%$. Thus, based on this statement, it can be concluded that the level of creative thinking ability of fifth graders at SDN Pasayangan is still low.

Therefore, researchers chose one alternative to solve problems related to students' creative thinking skills by using interactive and interesting learning media in the form of board games that were tailored to the needs of material delivery and student needs. Amelia et al., (2019) learning media are everything both physical and technical in the learning process that can help teachers to make it easier to convey subject matter to students so as to facilitate the achievement of learning objectives. One of the media that researchers can use is board game learning media (board games). The board game Risk consists of two or more players, players compete against each other on a global map with the ultimate goal of conquering all continents. Many common variations include sub-objectives and missions to complete the game, each player can win by completing certain tasks according to the received mission, it can also be a player defending or even occupying more territory at that time (Bernosky, 2016a; Hempel-Jorgensen, 2015). Regarding the problem of creative thinking skills, this Risk board game is very suitable to be able to help train and develop students' creative thinking skills, 
because this board game requires accuracy and consideration of the players' steps. Not just shuffling the dice and running according to the dice numbers but this game requires careful thinking to choose and weigh where the players will go, just like a chess board game but in the design the shape is poured in the form of a map that is in the form of real or fantasy plus there are various missions that players must complete in order to win the game. The missions available in the Risk board game really need the ideas and thoughts of each student as a player to be able to choose steps for territory struggle and problem solving, this is very much in line with the indicators of creative thinking ability. Thus, it is clear that the Risk board game is suitable to be a medium to help train and develop students' creative thinking skills (Bernosky, 2016b; Mostowfi et al., 2016).

One of the studies that uses board games as a problem-solving tool is a study conducted by Mostowfi et al., (2016)with the results stating that after being given learning using board games, the average score of their learning outcomes was 82.79, while students who taught without board games got a mean score of 74, 29 . These data indicate that students who are taught using board games get higher scores than those who learn without board games. This study is different from research conducted by other researchers, because this study uses the Risk board game as a problem-solving tool, and the problem to be solved is the problem of students' creative thinking skills. Although no one has conducted research on the board game Risk on the creative thinking ability of elementary school students, some previous studies are considered the most relevant by researchers to support the research that will be carried out. Several studies that are considered relevant explain that the use of board game media has positive results to help solve problems related to learning, therefore the use of Risk board game media can be said to be relevant to be able to solve problems related to students' creative thinking skills. Based on this, the purpose of this study is to describe the use of Risk Board game learning media in social studies learning content.

\section{METHODS}

This research uses Quasi Experimental quantitative research. This study has a control group, but it cannot function fully to control external variables that affect the implementation of the experiment. The experimental design used 
by the researcher is the Non-equivalent Control Group Design, in which the experimental group or control group is not selected randomly (Sugiyono, 2017). An overview of the design is as follows:

Table 2. Non-Equivalent Control Group Design

\begin{tabular}{cccc}
\hline \multicolumn{2}{l}{ Pretest Class } & Treatment & Postest Class \\
\hline$E$ & $O_{1}$ & $X_{E}$ & $O_{2}$ \\
$K$ & $O_{1}$ & $X_{K}$ & $O_{2}$ \\
\hline
\end{tabular}

Information :

$\mathrm{E}=$ Experimental group that received treatment using the board game learning media Risk Rulers of the Archipelago.

$\mathrm{K}=$ Control group who received treatment using picture learning media.

$X_{E}=$ Treatment using board game learning media Risk Rulers of the Archipelago.

$X_{K}=$ Treatment using image learning media.

$\mathrm{O}_{1}=$ Initial test before treatment is given .

$\mathrm{O}_{2}=$ Final test after treatment is given .

This research was conducted at SD Negeri Pasayangan, Lebakwangi District, Kuningan Regency. The time of this research was carried out in the even semester of the 2020/2021 academic year, namely in March 2021. The research subjects were 31 students of class V. The researcher chose SD Negeri Pasayangan as the place of research because the research subjects were very heterogeneous in terms of their abilities, namely there were those who had high, medium and low abilities. The research instrument used a description test with the validity value measured using the product moment correlation. The calculation results show that $\mathrm{r}_{\text {count }}>\mathrm{r}_{\text {table' }}$ it can be concluded that all items are valid, so the researcher decides to take all valid questions even though there is a slight improvement in the questions. Then the reliability of the instrument using the Cronbach Alpha formula with a score of 0.96 so that the reliability test analysis on the test questions has a very high level of reliability. The data collection tool in this study is a test. The type of data obtained from the research results is quantitative interval data which will then be analyzed by statistical tests which include four tests, namely normality test, homogeneity test, n-gain test and hypothesis testing. 


\section{RESULTS AND DISCUSSION}

The results of the study were described through the acquisition of scores of students in the experimental class and control class at the pretest and posttest stages. The following are the results of student scores which are described in tabular form.

Table 3. Pretest and Posttest Results

\begin{tabular}{llcc}
\hline \multirow{2}{*}{ Class } & Description & \multicolumn{2}{c}{ Score } \\
\cline { 3 - 4 } & & Pretest & Posttest \\
\hline \multirow{3}{*}{ Experiment } & Amount & 535 & 1330 \\
& Average & 80 & 82,84 \\
& Max value & 35 & 100 \\
& Min value & 785 & 70 \\
& Amount & 52,40 & 70,67 \\
& Average & 75 & 90 \\
& Max value & 35 & 55 \\
\hline
\end{tabular}

Based on table 3 above, it can be seen that in the pretest, the experimental class obtained an average score of 52.60 with a maximum value of 80.00 and a minimum value of 35 with a standard deviation of 12.73 . While the control class obtained an average value of 52.40 with a maximum value of 75 and a minimum value of 35 with a standard deviation of 19.10. This shows that the results of the pretest before doing the learning have different averages and show that students' creative thinking skills are still low. Furthermore, in the posttest, it can be seen that the experimental class obtained an average value of 83.13 with a maximum value of 100 and a minimum value of 70 with a standard deviation of 9.1 While the value obtained by the control class averaged 70.67 with a maximum value of 90 and the minimum value is 55 with a standard deviation of 10.54 . This shows that the posttest results after learning have different averages and different students' creative thinking abilities. Furthermore, the data that has been obtained from the results of the pretest and posttest are then calculated and analyzed using the normality test and homogeneity test. The following are the results of the normality test analysis. 
The Use of Risk Board Game Rulers of Archipelago as Learning Media on Creative Thinking Ability ......

Table 4. Normality Test of Pretest Data for Control Class and Experiment Class

\begin{tabular}{lcc}
\hline \multirow{2}{*}{ Statistics } & Control Class & Experiment Class \\
\cline { 2 - 3 } \multicolumn{2}{c}{ Pretest } \\
\hline Average & 52,40 & 52,60 \\
Standard deviation & 19,10 & 12,73 \\
$X^{2}{ }_{\text {Count }}$ & 4,292 & 3,813 \\
$X^{2}{ }_{\text {Table }}$ & 5,991 & 5,991 \\
Description & $4,292<5,991$ & $3,813<5,991$ \\
Conclusion & Normal Distribution & Normal Distribution \\
\hline
\end{tabular}

Based on table 4 above, it can be seen that the results of the normality test of the pretest data in the experimental class obtained $X^{2}$ count of 4.292 and control class $X^{2}$ of 3.813 while the value of $X^{2}$ Table for the experimental class and control class was 5.991. Judging from the data above, the value of $X^{2}$ Count from the experimental and control classes is less than or less than the $X^{2}$ table, so the pretest values of the experimental class and control class are normally distributed.

Table 5. Normality Test of Posttest Data for Control Class and Experiment Class

\begin{tabular}{lcc}
\hline \multirow{2}{*}{ Statistics } & Control Class & Experiment Class \\
\cline { 2 - 3 } & \multicolumn{2}{c}{ Posttest } \\
\hline Average & 70,67 & 82,84 \\
Standard Deviation & 10,54 & 9,1 \\
$\mathrm{X}^{2}$ Count & 4,869 & 5,337 \\
$\mathrm{X}^{2}{ }_{\text {Table }}$ & 5,991 & 5,991 \\
Descripton & $4,869<5,991$ & $5,337<5,991$ \\
Conclution & Normal Distribution & Normal Distribution \\
\hline
\end{tabular}

Based on table 5 above, it can be seen that the results of the posttest data normality test in the experimental class obtained $X^{2}$ count of 5.337 and control class $\mathrm{X}^{2}$ of 4.869 while the value of $\mathrm{X}^{2}$ Table for the experimental class and control class was 5.991. Judging from the data above, the value of $X^{2}$ Count from the experimental and control classes is less than or less than the $\mathrm{X}^{2}$ table, so the posttest values of the experimental class and control class are normally distributed. Furthermore, the homogeneity test of the pretest and posttest of the control and experimental classes was carried out in the following table. 
Table 6. Homogeneity Test of Pretest Data for Experiment Class and Control Class

\begin{tabular}{ccc}
\hline \multirow{2}{*}{ Statistics } & \multicolumn{2}{c}{ Pretest } \\
\cline { 2 - 3 } & Experiment & Control \\
\hline Variance & 162,05 & 364,81 \\
$\mathrm{~F}_{\text {hitung }}$ & \multicolumn{2}{c}{0,444} \\
$\mathrm{~F}_{\text {tabel }}$ & 4,18 \\
$\mathrm{n}_{1}$ & 16 \\
$\mathrm{n}_{2}$ & 15 \\
Description & \multicolumn{2}{c}{ Homogeneous } \\
\hline
\end{tabular}

Based on the results of the calculation of the homogeneity test using the $\mathrm{F}$ test, it is obtained that $\mathrm{F}_{\text {coun }} \mathrm{t}<\mathrm{F}_{\text {table }}$. From the results of the pretest data calculation for the experimental class and the control class, $\mathrm{F}_{\text {count }}$ is 0.444 and $<\mathrm{F}_{\text {table }} 4.18$. So it can be concluded that the value of $\mathrm{F}_{\text {count }}(0.444)<\mathrm{F}_{\text {table }}(4.18)$ the variance of the pretest data for the experimental class and the control class is homogeneous.

Table 7. Homogenity Test of Posttest Data for Experiment Class and Control Class

\begin{tabular}{ccc}
\hline \multirow{2}{*}{ Statistics } & \multicolumn{2}{c}{ Posttest } \\
\cline { 2 - 3 } & Experiment & Control \\
\hline Variance & 82,81 & 111,09 \\
$\mathrm{~F}_{\text {hitung }}$ & 0,745 \\
$\mathrm{~F}_{\text {tabel }}$ & 4,18 \\
$\mathrm{n}_{1}$ & 16 \\
$\mathrm{n}_{2}$ & 15 \\
Description & Homogeneous \\
\hline
\end{tabular}

Based on the results of the homogeneity test calculation using the $\mathrm{F}$ test, $\mathrm{F}_{\text {count }}$ $<\mathrm{F}_{\text {table }}$ with a significant level of $5 \%$ or 0.05 . $\mathrm{Ft}_{\text {able }}(17 / 17)=4.18$. From the results of the posttest data calculation for the experimental class and the control class, $\mathrm{F}_{\text {count }}$ is 0.75 . So it can be concluded that the value of $\mathrm{F}_{\text {count }}(0.75)<\mathrm{F}_{\text {table }}(4.18)$ for the posttest data variant of the experimental class and the homogeneous control class. Then the analysis of the difference test is described in the following table. 
Table 8. Test Results Differences in Students' Creative Thinking Ability

\begin{tabular}{lllll}
\hline $\mathbf{S}_{\text {Combined }}$ & $\mathbf{T}_{\text {Count }}$ & $\mathbf{t}_{\text {table }}$ & Description & Conclution \\
\hline 9,82 & 3,33 & 1,70 & $\mathrm{~T}_{\text {count }}>\mathbf{t}_{\text {table }}$ & $\mathrm{H}_{0}$ Rejected \\
\hline
\end{tabular}

Based on table 8 above, it can be concluded that the combined $S$ obtained from the two posttest data averages for the experimental class and the control class is 9.82. With a tcount of 3.33 and a $t$-table of 1.70. The value of $t_{\text {coun }} t>t_{\text {table }}$ then $\mathrm{H}_{0}$ is rejected. And based on the results of the two-party t-test, it can be concluded that there are differences in the creative thinking abilities of students who study using the board game Risk Rulers of the Archipelago learning media with those using image learning media. The results of increasing creative thinking skills are described in the following table.

Table 9. Test Results for Improving Students' Creative Thinking Ability

\begin{tabular}{lllll}
\hline $\mathbf{S}_{\text {Combined }}$ & $\mathbf{T}_{\text {count }}$ & $\mathbf{t}_{\text {table }}$ & Description & Conclution \\
\hline 0,23 & 6,87 & 1,70 & $\mathrm{~T}_{\text {count }}>\mathrm{t}_{\text {table }}$ & $\mathrm{H}_{0}$ Rejected \\
\hline
\end{tabular}

Based on table 9, it can be concluded that the combined $S$ obtained from the two posttest data averages for the experimental class and the control class is 0.23 . With a tcount of 6.87 and a $t$-table of 1.70. The value of $t_{\text {count }}>t_{\text {table }}$ then $H_{0}$ is rejected. And based on the results of the two-party t-test, it can be concluded that there is an increase in the creative thinking ability of students who learn by using the learning media of the Risk Rulers of the Archipelago board game by using image learning media. Furthermore, the N-Gain Pretest Posttest test in the control and experimental classes is as follows.

Table 10. N-Gain Test Pretest-Posttest Control Class and Experiment Class

\begin{tabular}{ccccc}
\hline Class & Min Value & Max Value & N-Gain & Conclution \\
\hline Control & 35 & 90 & 5,452 & Moderate \\
Experiment & 35 & 100 & 10,684 & High \\
\hline
\end{tabular}


Based on table 10 above, it can be seen that the average value of n-gain obtained by the experimental class is 1.257 with a high interpretation, the lowest value is 0.375 and the highest value is 100 . While the average value of $n$-gain obtained by the control class is 0.688 with an interpretation. low, the lowest value is -0.167 and the highest value is 0.700 . The difference in the average value of the $\mathrm{n}$-gain score obtained by the experimental class and the control class is 0.57 .

In the test results on the initial test of the difference in students' creative thinking abilities, it is known that the average value of the experimental class is 52.60 , not much different from the control class of 52.40. This shows that before being given treatment, students in the experimental class and control class have the same creative thinking ability. This means that there are still shortcomings where students' creative thinking skills are still not optimal in the learning process. This can be influenced by several things, including the use of learning media that is less than optimal and less varied, which is the basis for the low creative thinking ability of students. This is in line with the research of Syawaluddin et al., (2020) Therefore, the use of media needs to be maximized to assist in the learning process so that students can improve their creative thinking skills.

After the experimental class and control class were treated for 3 times the experimental class treatment and the control class were given a final test (posttest). Furthermore, seen in the table above, the results of the posttest experimental class and control class there are significant differences in average. The difference in the average value of the pretest experimental class is 52.60 and the posttest is 82.84 . While the average value of the pretest control class is 52.00 and the posttest is 70.67. This shows that the experimental class and the control class show differences in creative thinking abilities after being given treatment. However, when compared between the experimental class and the control class, it can be seen that the difference is quite significant where the experimental class shows a higher percentage of improvement than the control class after being given treatment. The factor that influences this is the learning media used in the experimental class. The media used in the experimental class is the board game learning media, Risk Rulers of the Archipelago. These instructional media steps foster creativity in solving problems faced by students, so that students' creative thinking skills are increasingly trained and motivated in developing their abilities 
and talents. As explained by Ucus (2017) with strategy-based games, students can recognize their abilities and potential in individual and group work, they will develop themselves and improve themselves, the habit of learning to use strategy-based games is very useful for developing attitudes and behaviors to create solutions. and alternative strategies without fear in case of failure. As a result, students who use strategy learning patterns through the media board game Risk Rulers of the Archipelago are more trained in their self-confidence to be able to have more creative thinking skills. In addition, fun learning through board games makes students more active in learning because the play atmosphere that has educational value makes students not bored and bored quickly. By using the learning media board game Risk Rulers of the Archipelago, students become more aware of the material given, namely the social studies content on theme 7 sub-theme 1 regarding events during the colonial period. This makes the creative thinking ability of the experimental class students more significantly different from the creative thinking ability of the control class students.

From the description above, it can be said that the learning media of the Risk Rulers of the Archipelago board game has provided a stimulus and response that functions as an educational game tool that can facilitate teachers and students in the teaching and learning process, especially on the subject matter of Social Sciences theme 7 sub-theme 1 regarding material events in the past. colonialism, this is also supported by the results of observations which show that in the experimental class at the first treatment meeting, students were still not able to display creative thinking indicators during learning, but at the second and third meetings the increase in students in demonstrating their creative thinking skills was getting better, the overall observation of the experimental class students continues to provide an overview of increasing creative thinking skills which is reflected in the student's actions during the learning process so that at the last meeting stage, the experimental class students as a whole can be categorized as having This is in line with the research by Setiawati et al., (2019) that board games can improve learning outcomes in social studies learning in elementary schools.

Based on the results of the N-gain test, the experimental class obtained an average value of 1.257 while the control class obtained an average value of 0.688 . From these data, the experimental class was included in the high classification and 
the control class was included in the medium classification. This shows that there is an increase in the control class and the experimental class but the difference is quite significant in the experimental class compared to the control class. And also shows that the experimental class has a higher improvement than the control class because the experimental class uses the Risk Rulers Nusantara board game learning media so that it can help teachers and students in the learning process.

The creative thinking ability of students is very important because the creative thinking ability of elementary school students is a process where students think of various solutions to a problem they face. As explained by Fitriyani et al., (2021) explains that creative thinking is a process that produces various possible answers. That way the demands of problem solving are not fixed on one problem solving or on one answer only, students are free to convey their answers according to their thoughts but still in accordance with the context of the problems at hand.

The Risk Board game, the ruler of the archipelago, is very suitable to be able to help train and develop students' creative thinking skills, because this board game requires accuracy and consideration of the players' steps. Bernosky (2016) with results stating that students who are taught using board games get higher scores than those who learn without board games. Not just shuffling the dice and running according to the dice numbers but this game requires careful thinking to choose and weigh where the players will go, just like a chess board game but in the design the shape is poured in the form of a map that is in the form of real or fantasy plus there are various missions that players must complete in order to win the game. The missions available on the Risk board game really need the ideas and thoughts of each student as a player to be able to choose steps for territorial struggles and problem solving, this is very in line with the indicators of creative thinking ability so it is clear that the Risk board game is suitable for can be a medium to help train and develop students' creative thinking skills.

In addition to elaboration through tests, the strengthening of the hypothesis is also described by the results of observations which show that at the first treatment meeting, students were still not so able to display indicators of creative thinking during the learning process, but at the second and third meetings the improvement of students in demonstrating their creative thinking skills was getting better, the overall observation of the experimental class students continues 
to provide an overview of increasing creative thinking skills which is reflected in the actions of students during the learning process so that at the last meeting stage, the experimental class students as a whole can be categorized as successful in developing their creative thinking skills with the help of board game learning media Risk Rulers of the Archipelago. In contrast to the experimental class, the control class at the beginning did show the same quality as the experimental class, but at the next meeting it could not show a significant change with the final results of observations showing that the increase between the experimental class and the control class was different from the experimental class which showed more improvement. significant creative thinking ability to the learning process.

But besides that, there are problems that occur when the research is carried out, the ongoing Covid-19 pandemic has hampered the efficiency of research time. Some of the factors that are problematic include the ongoing pandemic situation as well as government regulations and schools where research is carried out on pandemic conditions that require learning to be carried out by home visits, making it difficult for researchers to contact the school at certain times when the teacher is studying at an unknown address. by researchers. In addition, research that must be carried out outside of school makes some preparations for learning a little disrupted due to differences in the atmosphere and conditions of the learning environment for both researchers and students as research subjects. As a result, researchers have to work extra to make field improvisations and immediately adjust learning conditions so that learning can be carried out and can be successful in accordance with the goals and expectations. Learning that requires students to learn not in a school environment requires students to adapt to different learning conditions. The condition of the learning environment that is not suitable causes students to slightly reduce their learning focus.

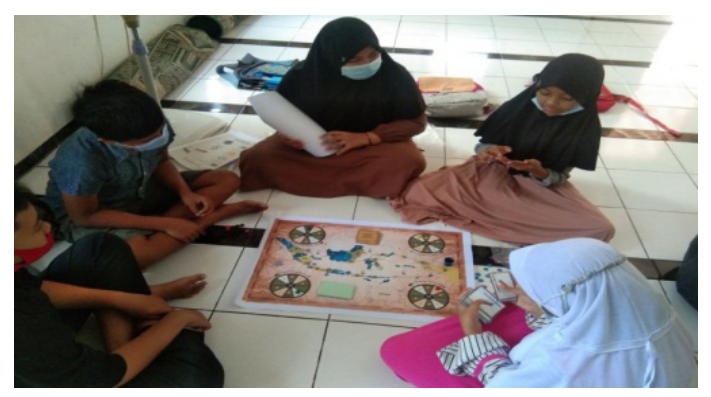

Figure 1. Students are learning to use the media Risk 


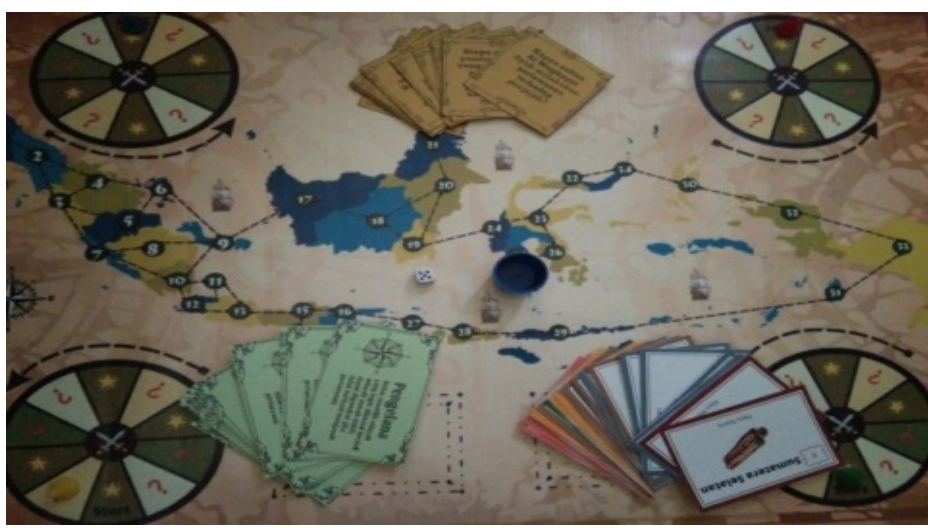

Figure 2. Media Game Board Risk

\section{CONCLUSION}

Based on the results of data analysis that has been obtained from a quasiexperimental research process in the content of social studies subjects on theme 7 sub-theme 1 by using the board game Risk Rulers of the Archipelago learning media and by using image learning media at SD Negeri Pasayangan, Lebakwangi District, Kuningan Regency, it can be concluded that there are the difference in the increase (n-gain) of students' creative thinking skills in the experimental class using the Risk Ruling Archipelago board game learning media with the control class using image learning media, the difference in creative thinking skills seen in the experimental class which has much higher creative thinking ability than the experimental class. creative thinking in the control class. From the results of the discussion, it can be concluded that using the board game learning media, Risk Rulers of the Archipelago, provides a good and significant difference and improvement in students' creative thinking skills compared to those using image learning media. So that the use of the board game Risk Rulers of the Archipelago media is very influential on students' creative thinking skills compared to those using image learning media. 


\section{REFERENCES}

Amelia, V. L., Setiawan, A., \& Sukihananto, S. (2019). Board Game as an Educational Game Media to an Effort to Change the Attitude of Dengue Prevention in School-Aged Children. International Journal of Nursing and Health Services (IJNHS), 1(2), 1-9. https:/ / doi.org/10.35654/ijnhs.v1i2.12

Arikunto, S. (2017). Prosedur Penelitian: Suatu Pendekatan Praktik. Jakarta: PT. Rineka Cipta.

Bernosky, J. (2016a). Manager to Manager-Risk: Not just a board game. Journal American Water Works Association, 108, 22-25. https://doi.org/10.5942/ jawwa.2016.108.0063

Bernosky, J. (2016b). Risk: Not Just a Board Game. Journal - American Water Works Association, 108, 22-25. https:/ / doi.org/10.5942/jawwa.2016.108.0063

Depdiknas. (2003). Undang-undang RI No.20 tahun 2003. Tentang Sistem Pendidikan Nasional.

Fitriyani, Y. (2021). Peningkatan Kemampuan Berpikir Kreatif Siswa melalui Pedagogik Kreatif pada Pembelajaran IPS di Sekolah Dasar (Penelitian Tindakan pada siswa Kelas VI SD Negeri 1 Awirarangan Kabupaten Kuningan) [Universitas Pendidikan Indonesia]. http:/ / repository.upi.edu/id/eprint/62935

Fitriyani, Y., Supriatna, N., \& Sari, M. Z. (2021). Pengembangan Kreativitas Guru dalam Pembelajaran Kreatif pada Mata Pelajaran IPS di Sekolah Dasar. Jurnal Kependidikan: Jurnal Hasil Penelitian Dan Kajian Kepustakaan Di Bidang Pendidikan, Pengajaran Dan Pembelajaran, 7(1), 97. https:/ / doi. org/10.33394/jk.v7i1.3462

Hempel-Jorgensen, A. (2015). Learner agency and social justice: what can creative pedagogy contribute to socially just pedagogies? Pedagogy, Culture and Society, 23(4), 531-554. https://doi.org/10.1080/14681366.2015.1082497

Kemendikbud. (2016). Permendikbud No 020 tahun 2016 Tentang Standar Kompetensi Lulusan Pendidikan Dasar Dan Menengah. Jakarta:Kemendikbud.

Kuntari, S. (2019). Relevansi Pendidikan Ips Dalam Arus Globalisasi. Hermeneutika: Jurnal Hermeneutika, 5(1), 25. https://doi.org/10.30870/ hermeneutika.v5i1.7389

Lucas, B. (2019). Teaching and assessing creativity in schools in England. Impact Journal, 7(September), 5-8.

Mostowfi, S., Mamaghani, N. K., \& Khorramar, M. (2016). Designing playful learning by using educational board game for children in the age range 
of 7-12: (A case study: Recycling and waste separation education board game). International Journal of Environmental and Science Education, 11(12), 5453-5476.

Setiawati, T., Pranata, O. H., \& Halimah, M. (2019). Pengembangan Media Permainan Papan pada Pembelajaran Ips untuk Siswa Kelas V Sekolah Dasar. PEDADIDAKTIKA: JURNAL ILMIAH PENDIDIKAN GURU SEKOLAH DASAR, 6(1), 163-174.

Simbolon, M. E., Rosyana, D., Fitriyani, Y., Guru, P., Dasar, S., Kuningan, U., Dasar, P., Indonesia, U. P., \& Dasar, S. (2021). Pengaruh Penerapan Media Pembelajaran Pop- Up Book Terhadap Hasil Belajar Siswa Sekolah. ADI WIDYA: Jurnal Pendidikan Dasar, 6(1), 34-45.

Sugiyono. (2017). Metode Penelitian Kuantitatif, Kualitatif, dan RED. Bandung: Alfabeta, CV.

Supriatna, N. (2019). Pengembangan Kreativitas Imajinatif Abad Ke-21 Dalam Pembelajaran Sejarah. Historia: Jurnal Pendidik Dan Peneliti Sejarah, 2(2), 73. https:// doi.org/10.17509/historia.v2i2.16629

Susanto, A. (2017). Pengembangan Pembelajaran IPS. Prenadamedia Group.

Suwandari, S., Ibrahim, M., \& Widodo, W. (2019). Application of Discovery Learning to Train the Creative Thinking Skills of Elementary School Student. International Journal of Innovative Science and Research Technology, $4(12), 410-417$.

Syawaluddin, A., Afriani Rachman, S., \& Khaerunnisa. (2020). Developing Snake Ladder Game Learning Media to Increase Students' Interest and Learning Outcomes on Social Studies in Elementary School. Simulation and Gaming, 51(4), 432-442. https:/ / doi.org/10.1177/1046878120921902

Ucus, S. (2017). Exploring Creativity in Social Studies Education for Elementary Grades: Teachers' Opinions and Interpretations. Journal of Education and Learning, 7(2), 111. https:// doi.org/10.5539/jel.v7n2p111

Vidergor, H. E. (2017). Effectiveness of the multidimensional curriculum model in developing higher-order thinking skills in elementary and secondary students. The Curriculum Journal, 5176(May), 1-21. https:/ / doi.org/10.10 80/09585176.2017.1318771

Zevin, J. (2015). Social studies for the twenty-first century: Methods and materials for teaching in middle and secondary schools. Routledge.

Zuraida, U. (2017). Peningkatan Kreativitas Peserta Didik dalam Pembelajaran Tematik di Kelas I. Jurnal Pendidikan Dasar Indonesia, 2(2), 18-24. 